\title{
Oral progesterone supplementation for beef cattle after insemination in TAl programs
}

\author{
Marcus Vinícius Galvão Loiola(1), Rodrigo Freitas Bittencourt(1), \\ Alexandra Soares Rodrigues ${ }^{(2)}$, Priscila Assis Ferraz ${ }^{(1)}$, Marcos Chalhoub Coelho Lima ${ }^{(1)}$, \\ Caio Victor Damasceno Carvalho(1) and Antonio de Lisboa Ribeiro Filho(1)
}

\begin{abstract}
(1)Universidade Federal da Bahia, Escola de Medicina Veterinária e Zootecnia, Avenida Ademar de Barros, no 500, Ondina, CEP 40170-110 Salvador, BA, Brazil. E-mail: vinicius_mev@hotmail.com, rfbvet@yahoo.com.br, prisferraz@gmail.com, chalhoub@ufba.br, caiovictor3@gmail.com, alisboafilho@ufba.br ${ }^{(2)}$ Universidade Federal do Oeste da Bahia, Centro Multidisciplinar da Barra, Rua 23 de Agosto, no 860, CEP 47100-000 Barra, BA, Brazil. E-mail: alexandravet_19@yahoo.com.br
\end{abstract}

\begin{abstract}
The objective of this work was to evaluate the effects of supplementation with melengestrol acetate (MGA), after timed artificial insemination (TAI), on the conception rate of Nellore cows, according to cyclicity during the protocol, estrus expression between intravaginal device withdrawal and insemination, and diameter of the largest follicle at the time of insemination, in order to identify predictors of the use of MGA. Multiparous lactating cows (577) were subjected to a hormonal protocol for ovulation synchronization. On day -2 of the protocol, the animals were painted with a marker on the base of their tail. On day 0 , they were evaluated for estrus expression; the preovulatory follicle diameter (POFD) was measured by ultrasonography, and the artificial insemination was performed. The animals were assigned to two experimental groups according to the supplementation or not with $0.50 \mathrm{mg}$ MGA, between 13 and 18 days after TAI. Pregnancy diagnosis was performed using an ultrasound examination 35 days after TAI. A positive effect of the treatment with MGA on the conception rate occurred generally in animals in anestrus, irrespective of the estrus expression. For animals treated with MGA, only those with POFD greater than $14 \mathrm{~mm}$ showed better conception rates that the control group.
\end{abstract}

Index terms: anestrous, bovine, fertility, insemination, melengestrol acetate.

\section{Suplementação com progesterona oral para gado de corte após a inseminação em programas de IATF}

Resumo - O objetivo deste trabalho foi avaliar o efeito da suplementação com acetato de melengestrol (MGA), após a inseminação artificial em tempo fixo (IATF), sobre a taxa de concepção de fêmeas bovinas da raça Nelore, de acordo com a ciclicidade durante o protocolo, a expressão do estro entre a retirada do dispositivo intravaginal e a inseminação, e o diâmetro do maior folículo no momento da inseminação, para determinar preditores da utilização do MGA. Fêmeas multíparas lactantes (577) foram submetidas a um protocolo hormonal de sincronização da ovulação. No dia -2 do protocolo, foram pintadas com bastão marcador na base da cauda. No dia 0 , foram avaliadas em relação à expressão do estro; a mensuração do diâmetro do folículo pré-ovulatório (DFOL) foi feita por ultrassonografia, e a inseminação artificial foi realizada. Os animais foram distribuídos em dois grupos experimentais de acordo com a suplementação ou não com $0,50 \mathrm{mg}$ de MGA entre 13 e 18 dias após IATF. O diagnóstico de gestação foi realizado por exame ultrassonográfico 35 dias após IATF. Um efeito positivo do tratamento com MGA sobre a taxa de concepção ocorreu, em geral, nos animais em anestro, independentemente da expressão do estro. Nos animais tratados com MGA, apenas os com DFOL acima de $14 \mathrm{~mm}$ apresentaram melhores taxas de concepção que o grupo-controle.

Termos para indexação: anestro, bovino, fertilidade, inseminação, acetato de melengestrol.

\section{Introduction}

Reproductive efficiency is the most influential factor in the productivity and profitability of beef cattle ranching (Baruselli, 2016). However, despite highfertilization rates (90 to $95 \%$ ) in fixed-time artificial insemination programs (TAI), 29 to $39 \%$ of embryos do not develop to term, which negatively impacts the final results of the breeding seasons (Wiltbank et al., 2016).

These losses in the early stages of gestation are a reflection of the complexity of the embryo preimplantation period, which includes the interval 
between oocyte fertilization and implantation of the conceptus (Diskin et al., 2011). In this gestational stage, the glandular epithelium of the endometrium is stimulated to proliferate and produce substrates, amino acids, and growth factors, among other histotrophic secretions (uterine milk) that will nourish the embryo until the moment of implantation. These secretions correspond to the first source of available nutrients to the conceptus and are produced under progesterone (P4) stimulation (Forde et al., 2009).

Low-circulating concentrations of P4 during the post-ovulatory period were associated with smaller embryos on day 16 and with a lower-secretion of interferon-tau (IFN- $\tau$ ), when it was ineffective at blocking the luteolytic process and maintaining pregnancy (Mann \& Lamming, 2001). However, the increase of their concentrations after TAI was associated with alterations in the expression of endometrial genes (Forde et al., 2009), which led to the progressive elongation of the conceptus, as well as to an increase in IFN- $\tau$ production (Carter et al., 2008) and higher-pregnancy rates in beef cows (Diskin \& Morris, 2008).

From this perspective, many studies have sought strategies to improve the plasma concentrations of P4 after insemination and, consequently, increase the fertility rates in TAI programs. Some of these strategies are the use of hCG, GnRH, or their analogs to facilitate the formation of an accessory corpus luteum and the supplementation with diverse sources of P4 (oral, injectable, intravaginal or auricular) (Loiola et al., 2014; Monteiro Jr. et al., 2015). Among the sources of progesterone available in the market, melengestrol acetate (MGA) stands out for being a synthetic progestational steroid that is orally administered, therefore it is convenient and does not require additional herd management for administration (Perez, 2005).

Increasing the plasma levels of $\mathrm{P} 4$ has been a success achieved by most researchers. However, when assessing the effects on fertility improvement, the results are quite inconsistent and have shown positive, negative, or noninterfering effects on conception rates (Yan et al., 2016).

Among the reasons for the discrepancies in the obtained results, it is possible to highlight the evaluation of the general conception rate in most of these studies that did not consider the variety of factors in the same group of females, which may affect the plasma concentrations of $\mathrm{P} 4$ at the onset of pregnancy differently. There may be a need for the exogenous support of this hormone within the same group of treated animals (Pugliesi et al., 2016).

To minimize the effects of these factors as to treatment with MGA on the conception rate, and due to the scarcity of such data in the literature, the effects of the treatment with $\mathrm{P} 4$ should be evaluated according to the following variables: ovarian cyclicity during the protocol, estrus expression, and diameter of the largest follicle at the time of TAI. We sought to confirm the hypothesis that treatment with MGA acts differently on each of these variables to improve the conception rate, especially in animals that have impaired fertility from a deficiency of follicular or luteal function, as described by Yan et al. (2016) after several studies on P4 supplementation.

The objective of this work was to evaluate the effects of supplementation with melengestrol acetate (MGA) after timed artificial insemination (TAI), on the conception rate of Nellore cows, according to the cyclicity during the protocol, the estrus expression between intravaginal device withdrawal and insemination, and the diameter of the largest follicle at the time of insemination, in order to identify predictors of MGA use.

\section{Materials and Methods}

The experiment was carried out from October to December 2015, on a commercial farm located in the region of Recôncavo Baiano (12²1'11"S, 38 22'44"W), Bahia state, Brazil. The region has an average annual rainfall of $1,400 \mathrm{~mm}$, and it is inserted in a humid tropical climate area whose predominant vegetation is the Atlantic Forest.

Multiparous lactating Nellore cows (Bos indicus), in a total of 577 animals of $6.74 \pm 3.25$ years of age, a body condition score (BSC) of $3.29 \pm 0.48$, on a scale from 1 to 5 (Ayres et al., 2009), and 31 to 58 days postpartum, were used. All animals were kept in paddocks, in a predominant pasture of Urochloa decumbens (Syn. Brachiaria decumbens), and received mineral supplementation and water ad libitum.

Before the beginning of synchronization, the animals underwent a gynecological examination by transrectal ultrasonography with a linear transducer of $6.0 \mathrm{MHz}$ 
frequency (Mindray, DP 2200 VET, São Paulo, SP, Brazil). Females that did not show reproductive tract abnormalities during the evaluation were considered eligible to participate in the experiment. To evaluate the ovarian cyclicity, this exam was repeated on the $8^{\text {th }}$ day of the protocol: females that did not show luteal tissue in either of the gynecological exams were considered in anestrus, and those that showed luteal tissue in at least one of the exams were considered to be cycling.

The animals were subjected to the following synchronization protocol (Figure 1): on a random day of the estrous cycle (D-10) they received an intravaginal P4 device (1 g, DIB, Zoetis, São Paulo, SP, Brazil), and $2 \mathrm{mg}$ of estradiol benzoate was administered intramuscularly (IM) (Gonadiol, Zoetis, São Paulo, SP, Brazil). On day -2 (D-2), the intravaginal device of P4 was removed, and $12.5 \mathrm{mg}$ of dinoprost tromethamine (IM) was administered (Lutalyse, Zoetis, São Paulo, SP, Brazil), followed by $1.0 \mathrm{mg}$ of estradiol cypionate (IM) (ECP, Zoetis, São Paulo, SP, Brazil), and 300 IU of eCG (IM) (Novormon, Zoetis, São Paulo, SP, Brazil). After removing the intravaginal device, the animals were painted with a marker stick (RAIDEX, GmbH, Dettingen/Erms, Germany) on the base of their tail to detect estrus. On day 0 (D-0), the inseminations were performed from 48 to 54 hours after removing the $\mathrm{P} 4$ devices, using cryopreserved semen from five Nellore bulls with established fertility. At the time of TAI, semen was thawed at $37^{\circ} \mathrm{C}$ for $30 \mathrm{~s}$, and all procedures were performed by the same technician.

Before performing the TAI, the measurement of the largest follicle (POFD) was carried out using transrectal ultrasonography and a linear transducer with a $6 \mathrm{MHz}$ frequency (Mindray, DP 2200 VET, São Paulo, SP, Brazil). The POFD was calculated from the mean of the two largest axes forming an angle of $90^{\circ}$ between them, and categorized as $<11 \mathrm{~mm}, 11$ to 14 $\mathrm{mm}$, or $>14 \mathrm{~mm}$. The expression of estrus or the lack of it was checked according to the status of the paint, at the base of the tail, at the time of insemination.

All procedures were performed in batches of up to 100 cows and repeated throughout the experiment for all of the evaluated animals. During TAI, each batch of animals subjected to treatment was randomly split into two experimental groups, according to supplementation with an exogenous source of P4. In the treatment with the use of MGA, the animals received supplements for 6 days - from the $13^{\text {th }}$ to the $18^{\text {th }}$ day after TAI -, with $0.50 \mathrm{mg}$ of MGA, which corresponds to $2.28 \mathrm{~g}$ per animal per day of MGA Premix (MGA), provided in the feeding trough along with mineral salt.

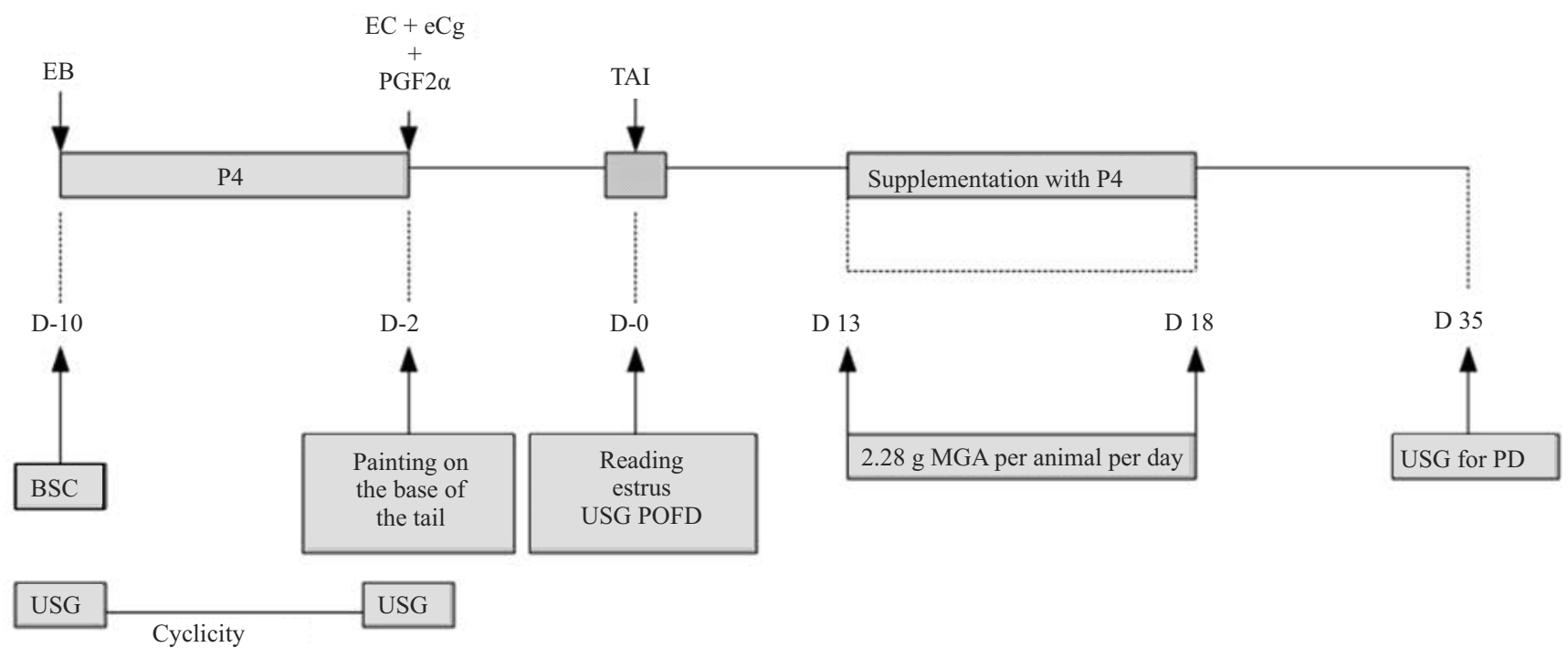

Figure 1. Diagram of the experimental design. BSC, body score condition; USG, ultrasonography; EB, estradiol benzoate; $\mathrm{P} 4$, progesterone from the device; $\mathrm{EC}$, estradiol cypionate; eCG, equine chorionic gonadotropin; $\mathrm{PGF}_{2} \alpha$, prostraglandin $\mathrm{F}_{2} \alpha$; POFD, preovulatory follicle diameter; MGA, melengestrol acetate; and PD, pregnancy diagnosis. 
In the treatments without MGA, the animals received the same type of mineral salt. These animals were managed under the same conditions as the treated group. To make the treated animals consume feed more homogeneously at each round of insemination, the treated group had a maximum of 50 animals.

The mineral supplement was provided according to the methods of Rodrigues et al. (2014), and the trough was assessed daily from the eighth day of insemination, in order to observe and record consumption in the morning and afternoon. The leftovers were weighed, if necessary, and the amount required per batch per day was adjusted, such that when the treatment with MGA started, the exact average of mineral salt intake per animal had already been defined for each batch. The amount of MGA corresponding to the daily consumption of the batch was added to the daily amount of mineral salt. To verify the MGA intake, the trough was also assessed every day, in the morning and in the afternoon, during treatment. From the nineteenth day onwards, MGA consumption was interrupted, and the animals from both groups started to consume mineral salt only.

Pregnancy was diagnosed by transrectal ultrasonography 35 days after insemination, and the conception rate was calculated by dividing the total number of pregnant cows by the total number of inseminated ones.

The information was analyzed using multivariate logistic regression in the Statistical Package for Social Science (SPSS), version 19 (IBM Corporation, Armonk, NY, USA), at 5\%, probability. To analyze the conception rate after TAI of all animals in the initial model, the following elements were included: effect of age postpartum; number of insemination rounds; ECC; ovarian cyclicity at the beginning of the protocol; diameter of the largest follicle at the time of insemination (POFD $<11 \mathrm{~mm}, 11$ to $14 \mathrm{~mm}$, or $>14 \mathrm{~mm}$ ); bull used for the insemination; expression or lack of expression of estrus between the removal of the intravaginal device and insemination; and supplementation with MGA from the $13^{\text {th }}$ to the $18^{\text {th }}$ day after TAI. Subsequently, the conception rates were compared between the experimental groups by applying a frequency dispersion study using the chisquare test. In the first phase of the analyses, only the MGA treatment groups (with MGA, $n=327$, and without MGA, $n=250$ ) were considered. In the second step, the interaction of the following variables was compared: cyclicity during the protocol, diameter of the largest follicle at the time of insemination, and expression or lack thereof for estrus between the removal of the intravaginal device and insemination, along with MGA treatment or the control treatment.

\section{Results and Discussion}

There were no effects of postnatal age, insemination rounds, body score condition, or the bull used for insemination, on the conception rates. In the present study, the average conception rate was $53.21 \%$ (307/577), which is similar to the rate observed by several authors who worked with beef cows (Bos indicus) in TAI programs (Ribeiro Filho et al., 2013; Rodrigues et al., 2014). In addition, a positive effect of the treatment with MGA was observed - between the $13^{\text {th }}$ and $18^{\text {th }}$ day after TAI - on the conception rate of the animals that received MGA (58.41\%), compared with that of the animals without supplementation with MGA (46.40\%) (Table 1). However, the individual factors, such as ovarian cyclicity at the beginning of the protocol, the diameter of the largest follicle at the time of insemination, and the expression or lack of expression for estrus between the withdrawal of the intravaginal device and insemination, affected the conception rate after TAI.

The MGA improvement of the conception rate in this period is justified, as it improved the uterine environment and stimulated the embryo during fetalmaternal signaling, which promoted gestation, as described by Silva Junior et al. (2014). According to these authors, multiparous Nellore cows achieved higher-pregnancy rates by the treatment with MGA between the $13^{\text {th }}$ and the $17^{\text {th }}$ day after the TAI protocol, which is a similar outcome to the results of the current study. In contrast, Rodrigues et al. (2014) evaluated the

Table 1. Conception rates for Nellore cows subjected to TAI program, treated or not with $0.5 \mathrm{mg}$ per day of melengestrol acetate $(\mathrm{MGA})^{(1)}$

\begin{tabular}{lcc}
\hline Treatment & Number of animals & Conception rate (\%) \\
\hline With MGA & 327 & $58.41 \mathrm{a}$ \\
Without MGA & 250 & $46.40 \mathrm{~b}$ \\
\hline Total & 577 & 53.21 \\
\hline
\end{tabular}

${ }^{(1)}$ Values followed by the same letter do not differ by chi-square test, at $5 \%$ probability. The supplementation with MGA was done between 13 and 18 days after insemination. 
effects of progesterone supplementation on fertility in Nellore cows by providing $2.28 \mathrm{~g}$ of MGA between the $13^{\text {th }}$ and $18^{\text {th }}$ days after insemination, and no significant difference in the conception rates of the treated animals $(50.00 \%)$ was observed, in comparison with the control group (42.16\%).

The variation of the results obtained with $\mathrm{P} 4$ supplementation after TAI can be justified by the fact that ovarian function affects the circulating level of progesterone at the time of supplementation. Further, for animals that have low-progesterone serum levels, supplementation may be beneficial, whereas for animals that show adequate progesterone serum levels, the supplementation will not show any benefit, which highlights the need for the evaluation of the ovarian condition to establish an appropriate strategy (Rodrigues et al., 2014).

According to previous studies, several factors may affect the conception rates of animals supplemented with $\mathrm{P} 4$, and this complexity can be noted in the experiments of Larson et al. (2009), who found positive effects on fertility, when dairy cows were supplemented with a progesterone intravaginal device; however, these authors found no improvement in beef cows that received the same treatment, at the same time, which suggested that there was a difference in response to treatment according to the type of animal that was treated (beef or dairy). Stevenson and Lamb (2016) proposed that physiological differences, including the circulating concentrations of progesterone and responses to supplemental progesterone, affected by the genotype and nutritional management of the animals, could account for the variation.

The timing of supplementation with P4 is another important factor for embryo survival, and it was studied by Yan et al. (2016) in a meta-analysis that evaluated P4 supplementation provided via injection or intravaginal administration in beef and dairy cows. These authors observed a beneficial effect of supplementation only when it was performed in the first week post-insemination, but no benefit was seen when supplementation was provided early $(<3$ days after artificial insemination, AI), or during the second or third week. In contrast, a satisfactory effect on the conception rate was found in the current study, in which supplementation with MGA occurred between days 13 and 18 after insemination. This result suggests that the progestogen type that was used (MGA) could justify these findings, as also could the period of supplementation.

Rodrigues et al. (2014) believed that providing this progestogen, in the first week after TAI, reduced conception rates in beef cows due to its mode of action, and promoted an inadequate endocrine environment. This may have been due to changes in uterine $\mathrm{pH}$ or to another factor that could make the embryonic growth and development nonviable in this period, according to Silva et al. (2015), who also observed a reduction in the conception rate in cows that received the same treatment in a similar period.

When the interaction of treatment with the cyclicity was evaluated, the effects of the supplementation with MGA could only be observed in the animals that were in anestrous (Table 2). Thus, the proposed hypothesis was supported, which indicates that there was a possible impairment in fertility, and a greater need for exogenous P4 support for females that were cycling.

According to previous studies, beef and dairy cows in postnatal anestrus, at the beginning of the TAI programs, had smaller follicles, which resulted in smaller or less functional CLs in relation to the production of P4 (Macmillan et al., 2003; Barreiros et al., 2014), thus justifying the better response of animals in anestrus at the beginning of the protocol, after the supplementation with MGA, in comparison with cycling animals.

This information was reinforced by Baruselli et al. (2004), who evaluated the conception rates according to the structures identified in the ovaries, during the gynecological exam prior to conducting the protocol for Nellore cows in TAI programs. According to these authors, the animals that had corpus luteum at

Table 2. Conception rate and cyclicity of Nellore cows subjected to a TAI protocol, with and without the use of 0.5 mg per day of melengestrol acetate $(\mathrm{MGA})^{(1)}$.

\begin{tabular}{lcc}
\hline Treatment & Number of animals & Conception rate (\%) \\
\hline \multicolumn{3}{c}{ Cycling cows } \\
With MGA & 130 & $61.54 \mathrm{a}$ \\
Without MGA & 75 & Anestrus \\
\hline \multicolumn{3}{c}{} \\
With MGA & 196 & $56.67 \mathrm{a}$ \\
Without MGA & 133 & $36.84 \mathrm{~b}$ \\
\hline Total & 534 & 53.18 \\
\hline
\end{tabular}

(1)Values followed by the same letter do not differ by chi-square test, at $5 \%$ probability. The supplementation with MGA was done between 13 and 18 days after insemination. 
the beginning of the protocol had higher conception rates $(55.5 \%)$ than did animals that had only $\geq 8 \mathrm{~mm}$ follicles (34.4\%), or those that had only $<8 \mathrm{~mm}$ follicles (29.4\%), which led to a difference in the response to the synchronization protocol, according to the prior ovarian conditions of the animals.

Following this same line of research, Pugliesi et al. (2016) tested the supplementation with another source of P4 (long-acting injectable), four days after ovulation, and measured the conception rates of Nellore females in TAI programs. These authors did not find a significant effect of this treatment when it was applied to animals with unknown ovarian conditions (anestrus or cycling). However, when the same treatment was performed only in lactating cows in anestrus, at the beginning of the protocol, the conception rates improved significantly.

Several studies have reported a high percentage of animals in anestrus, at the beginning of the protocol, in herds of lactating Zebu cows reared on pasture. Baruselli et al. (2002) found a low percentage (14.0\%) of lactating beef cows cycling between 60 and 70 days postpartum, and, according to Wheaton et al. (2007), in grazing systems, suckling beef cows at 30 to 40 days postpartum can show anestrus rate of up to $90 \%$, at which point they are included in TAI programs. Thus, the use of strategies that enable better results in this group of animals, as proposed in this experiment, is an alternative for improving the fertility of beef cows in large breeding systems in Brazil, and may be a practical alternative that does not require additional management.

Table 3. Conception rate and estrus expression of Nellore cows subjected to a TAI protocol, with and without the use of $0.5 \mathrm{mg}$ per day of melengestrol acetate (MGA) ${ }^{(1)}$.

\begin{tabular}{|c|c|c|}
\hline Treatment & Number of animals & Conception rate $(\%)$ \\
\hline & \multicolumn{2}{|c|}{ Expressing estrus } \\
\hline With MGA & 168 & $68.45 \mathrm{a}$ \\
\hline \multirow[t]{2}{*}{ Without MGA } & 104 & $52.88 \mathrm{~b}$ \\
\hline & \multicolumn{2}{|c|}{ Without estrus } \\
\hline Anestrus with MGA & 158 & $48.10 \mathrm{~b}$ \\
\hline Anestrus without MGA & 104 & $36.54 \mathrm{c}$ \\
\hline Total & 534 & 53.18 \\
\hline
\end{tabular}

Pesq. agropec. bras., Brasília, v.53, n.1, p.105-112, Jan. 2018 DOI: 10.1590/S0100-204X2018000100012
When considering the interaction of the treatment with the estrus expression of the animals, there was a positive effect of the MGA administration between the 13th and 18th day after TAI on the conception rate of Nellore cows, regardless of estrus expression (Table 3). As to the interaction of the treatment with MGA and POFD on the conception rate of the animals, no significant effect of the treatment was found on the animals with POFD $<11 \mathrm{~mm}$ and DFOL between 11 and $14 \mathrm{~mm}$. However, the animals with POFD >14 $\mathrm{mm}$ had better conception rates when supplemented with MGA between days 13 and 18 after insemination, in comparison with the nonsupplemented animals (Table 4).

According to Ferraz et al. (2017), Zebu females that were subjected to TAI programs and were expressing estrus during the protocol (between removal of the intravaginal device and the time of insemination) had a higher conception rate than animals that were not in estrus. Similarly, animals with larger follicle diameters at the time of insemination were more likely to become pregnant than those with follicles that had smaller diameters (Ribeiro Filho et al., 2013).

These satisfactory results for the conception rate of the animals observed in estrus during the synchronization protocol, and with animals that had larger follicles at the time of TAI, promoted a gene expression profile in reproductive tissues during the

Table 4. Conception rate and diameter of the largest follicle at the time of insemination (POFD) of Nellore cows subjected to TAI program, with and without the use of 0.5 mg per day of melengestrol acetate $(\mathrm{MGA})^{(1)}$.

\begin{tabular}{|c|c|c|}
\hline Treatment & Number of animals & Conception rate $(\%)$ \\
\hline & \multicolumn{2}{|c|}{ POFD $<11 \mathrm{~mm}$} \\
\hline With MGA & 109 & $44.04 \mathrm{c}$ \\
\hline \multirow[t]{2}{*}{ Without MGA } & 79 & $40.51 \mathrm{c}$ \\
\hline & \multicolumn{2}{|c|}{$\mathrm{POFD}=11-14 \mathrm{~mm}$} \\
\hline With MGA & 124 & $62.90 \mathrm{ab}$ \\
\hline \multirow[t]{2}{*}{ Without MGA } & 85 & $50.59 b c$ \\
\hline & \multicolumn{2}{|c|}{ POFD $>14 \mathrm{~mm}$} \\
\hline With MGA & 93 & $69.89 \mathrm{a}$ \\
\hline Without MGA & 44 & $40.91 \mathrm{c}$ \\
\hline Total & 534 & 53.18 \\
\hline
\end{tabular}

(1)Values followed by the same letter do not differ by chi-square test, at $5 \%$ probability. The supplementation with MGA was done between 13 and 18 days after insemination. 
preimplantation phase, and provided an adequate uterine environment for conception (Davoodi et al., 2016). Furthermore, adequate concentrations of E2 during the final follicular growth were positively correlated with the preovulatory follicle diameter and luteal function, which facilitated the establishment and maintenance of pregnancy (Bridges et al., 2012; Stevenson \& Lamb, 2016).

Based on this positive association between the circulating concentration of E2, at the time of insemination, and the serum P4 levels after ovulation which favors conception rates as shown by Atkins et al. (2013), the hypothesis can be proposed that animals with smaller preovulatory follicles, and that do not express heat, would have better results with MGA. However, under the conditions of this experiment, this effect was not confirmed.

Treatment with MGA significantly affected the conception rate of the groups, independently of estrus expression, and it was not effective on animals with small $(<11 \mathrm{~mm})$ or medium (11 to $14 \mathrm{~mm})$ follicles.

\section{Conclusions}

1. The treatment with MGA is effective for improving the conception rate of multiparous lactating Nellore cows in TAI programs, especially in anestrus animals, which means that it is possible to establish strategies for providing MGA, depending on the ovarian conditions of the animals.

2. Estrus expression and preovulatory follicle diameter are not effective as predictors for selecting animals to be supplemented with MGA.

\section{References}

ATKINS, J.A.; SMITH, M.F.; MACNEIL, M.D.; JINKS, E.M.; ABREU, F.M.; ALEXANDER, L.J.; GEARY, T.W. Pregnancy establishment and maintenance in cattle. Journal of Animal Science, v.91, p.722-733, 2013. DOI: 10.2527/jas.2012-5368.

AYRES, H.; FERREIRA, R.M.; TORRES-JÚNIOR, J.R. de S.; DEMÉTRIO, C.G.B.; LIMA, C.G. de; BARUSELLI, P.S. Validation of body condition score as a predictor of subcutaneous fat in Nelore (Bos indicus) cows. Livestock Science, v.123, p.175179, 2009. DOI: 10.1016/j.livsci.2008.11.004.

BARREIROS, T.R.R.; BLASCHI, W.; SANTOS, G.M.G.; MOROTTI, F.; ANDRADE, E.R.; BARUSELLI, P.S.; SENEDA, M.M. Dynamics of folicular growth and progesterone concentrations in cyclic and anestrous suckling Nelore cows (Bos indicus) treated with progesterone, equine chorionic gonadotropin, or temporary calf removal. Theriogenology, v.81, p.651-656, 2014. DOI: 10.1016/j.theriogenology.2013.12.008.

BARUSELLI, P.S. IATF supera dez milhões de procedimentos e amplia o mercado de trabalho. Revista CFMV, ano 22, p.5760, 2016. Available at: <https://altagenetics.com.br/Circulares/ IATF $\% 20$ supera $\% 20 \mathrm{dez} \% 20 \mathrm{milh} \% \mathrm{C} 3 \%$ B 5 es $\% 20 \mathrm{de} \% 20$ procedimentos $\% 20 \mathrm{e} \% 20$ amplia $\% 20 \mathrm{o} \% 20$ mercado $\% 20 \mathrm{de} \% 20$ trabalho.pdf>. Accessed on: Apr. 52017.

BARUSELlI, P.S.; MARQUES, M.O.; CARVALHO, N.A.T.; MADUREIRA, E.H.; CAMPOS FILHO, E.P. Efeito de diferentes protocolos de inseminação artificial em tempo fixo na eficiência reprodutiva de vacas de corte lactantes. Revista Brasileira de Reprodução Animal, v.26, p.218-221, 2002.

BARUSELLI, P.S.; REIS, E.L.; MARQUES, M.O.; NASSER, L.F.; BÓ, G.A. The use of hormonal treatments to improve reproductive performance of anestrous beef cattle in tropical climates. Animal Reproduction Science, v.82-83, p.479-486, 2004. DOI: 10.1016/j.anireprosci.2004.04.025.

BRIDGES, G.A.; MUSSARD, M.L.; PATE, J.L.; OTT, T.L.; HANSEN, T.R.; DAY, M.L. Impact of preovulatory estradiol concentrations on conceptus development and uterine gene expression. Animal Reproduction Science, v.133, p.16-26, 2012. DOI: 10.1016/j.anireprosci.2012.06.013.

CARTER, F.; FORDE, N.; DUFFY, P.; WADE, M.; FAIR, T.; CROWE, M.A.; EVANS, A.C.O.; KENNY, D.A.; ROCHE, J.F.; LONERGAN, P. Effect of increasing progesterone concentration from day 3 of pregnancy on subsequent embryo survival and development in beef heifers. Reproduction, Fertility and Development, v.20, p.368-375, 2008. DOI: 10.1071/RD07204.

DAVOODI, S.; COOKE, R.F.; FERNANDES, A.C.; CAPPELLOZZA, B.I.; VASCONCELOS, J.L.; CERRI, R.L.A. Expression of estrus modifies the gene expression profile in reproductive tissues on day 19 of gestation in beef cows. Theriogenology, v.85, p.645-655, 2016. DOI: 10.1016/j. theriogenology.2015.10.002.

DISKIN, M.G.; MORRIS, D.G. Embryonic and early foetal losses in cattle and other ruminants. Reproduction Domestic Animal, v.43, p.260-267, 2008. DOI: 10.1111/j.1439-0531.2008.01171.x.

DISKIN, M.G.; PARR, M.H.; MORRIS, D.G. Embryo death in cattle: an update. Reproduction, Fertility and Development, v.24, p.244-251, 2011. DOI: 10.1071/RD11914.

FERRAZ, P.S.; LOIOLA, M.V.G.; RODRIGUES, A.S.; LIMA, M.C.C.; BITTENCOURT, T.C.B. dos S.C. de; RIBEIRO FILHO, A. de L. The effect of the intensity of estrus expression on the follicular diameter and fertility of Nellore cows managed under a FTAI program. Ciência Animal Brasileira, v.18, p.1-9, e-37643, 2017. DOI: $10.1590 / 1089-6891 v 18 \mathrm{e}-37643$.

FORDE, N.; CARTER, F.; FAIR, T.; CROWE, M.A.; EVANS, A.C.O.; SPENCER, T.E.; BAZER, F.W.; MCBRIDE, R.; BOLAND, M.P.; O'GAORA, P.; LONERGAN, P.; ROCHE, J.F. Progesterone-regulated changes in endometrial gene expression contribute to advanced conceptus development in cattle. Biology of Reproduction, v.81, p.784-794, 2009. DOI: 10.1095/ biolreprod.108.074336. 
LARSON, J.E.; THIELEN, K.N.; FUNNELL, B.J.; STEVENSON, J.S.; KESLER, D. J.; LAMB, G.C. Influence of a controlled internal drug release after fixed-time artificial insemination on pregnancy rates and returns to estrus of nonpregnant cows. Journal of Animal Science, v.87, p.914-921, 2009. DOI: 10.2527/ jas.2008-1443.

LOIOLA, M.V.G.; PEREIRA, D.F.C.; VASCONCELOS, L.V.; LIMA, M.C.C.; FERRAZ, P.A.; RODRIGUES, A.S.; BITTENCOURT, R.F.; JESUS, E.O. de; RIBEIRO FILHO, A. de L. Taxa de gestação de receptoras de embriões bovinos tratadas com um análogo de GnRH no momento da inovulação. Revista Brasileira de Saúde e Produção Animal, v.15, p.782-789, 2014. DOI: $10.1590 / \mathrm{S} 1519-99402014000300025$.

MACMILLAN, K.L.; SEGWAGWE, B.V.E.; PINO, C.S. Associations between the manipulation of patterns of follicular development and fertility in cattle. Animal Reproduction Science, v.78, p.327-344, 2003. DOI: 10.1016/S0378-4320(03)00098-8.

MANN, G.E.; LAMMING, G.E. Relationship between maternal endocrine environment, early embryo development and inhibition of the luteolytic mechanism in cows. Reproduction, v.121, p.175180, 2001. DOI: 10.1530/rep.0.1210175.

MONTEIRO JR., P.L.J.; NASCIMENTO, A.B.; PONTES, G.C.S.; FERNANDES, G.O.; MELO, L.F.; WILTBANK, M.C.; SARTORI, R. Progesterone supplementation after ovulation: effects on corpus luteum function and on fertility of dairy cows subjected to AI or ET. Theriogenology, v.84, p.1215-1224, 2015. DOI: 10.1016/j.theriogenology.2015.06.023.

PEREZ, G.C. Uso do acetato de melengestrol (MGA), associado a PGF $2 \alpha$ e a GnRH ou benzoato de estradiol em protocolos de inseminação artificial em tempo fixo (IATF) para vacas Nelores paridas. 2005. 80p. Dissertação (Mestrado) - Universidade Estadual de São Paulo, São Paulo.

PUGLIESI, G.; SANTOS, F.B.; LOPES, E.; NOGUEIRA, É.; MAIO, J.R.G.; BINELLI, M. Improved fertility in suckled beef cows ovulating large follicles or supplemented with long-acting progesterone after timed-AI. Theriogenology, v.85, p.1239-1248, 2016. DOI: 10.1016/j.theriogenology.2015.12.006.

RIBEIRO FILHO, A. de L.; FERRAZ, P.A.; RODRIGUES, A.S.; BITTENCOURT, T.C.B.S.C.; LOIOLA, M.V.G.; CHALHOUB, M. Diâmetro do folículo no momento da inseminação artificial em tempo fixo e taxa de concepção em vacas Nelore. Ciência Animal Brasileira, v.14, p.501-507, 2013. DOI: 10.5216/cab.v14i4.19678.

RODRIGUES, M.C.; LEÃO, K.M.; SILVA, N. do C.; SILVA, R.P. da; VIU, M.A. de O.; CARDOSO, L.M. Administração de acetato de melengestrol após inseminação artificial em tempo fixo em vacas Nelore lactantes. Revista Brasileira de Saúde e Produção Animal, v.15, p.361-368, 2014. DOI: 10.1590/S151999402014000200024.

SILVA JUNIOR, L. de S. e; FREIRIA, L.B. da; ANGREVESSILVA, G.M.; POSSAMAI, A.J.; HATAMOTO-ZERVOUDAKIS, L.K.; SILVA, M.R. Uso do acetato de melengestrol após protocolos de inseminação artificial em tempo fixo em vacas Nelore multíparas. Revista Brasileira de Saúde e Produção Animal, v.15, p.425-429, 2014. DOI: 10.1590/S1519-99402014000200025.

SILVA, R.P. da; LEÃO, K.M.; RODRIGUES, M.C.; MARQUES, T.C.; SILVA, N. do C; VIU, M.A. de O. Aplicação de GnRH no dia da inseminação artificial em tempo fixo (IATF) e administração de acetato de melengestrol (MGA) após IATF em vacas nelore solteiras. Semina: Ciências Agrárias, v.36, p.3149-3160, 2015. DOI: $10.5433 / 1679-0359.2015 v 36 n 5 p 3149$.

STEVENSON, J.S.; LAMB, G.C. Contrasting effects of progesterone on fertility of dairy and beef cows. Journal of Dairy Science, v.99, p.5951-5964, 2016. DOI: 10.3168/jds.2015-10130.

WHEATON, J.E.; LAMB, G.C. Induction of cyclicity in postpartum anestrous beef cows using progesterone, $\mathrm{GnRH}$ and estradiol cypionate (ECP). Animal Reproduction Science, v.102, p.208-216, 2007. DOI: 10.1016/j.anireprosci.2006.11.006.

WILTBANK, M.C.; BAEZ, G.M.; GARCIA-GUERRA, A.; TOLEDO, M.Z.; MONTEIRO, P.L.J.; MELO, L.F.; OCHOA, J.C.; SANTOS, J.E.P.; SARTORI, R. Pivotal periods for pregnancy loss during the first trimester of gestation in lactating dairy cows. Theriogenology, v.86, p.239-253, 2016. DOI: 10.1016/j. theriogenology.2016.04.037.

YAN, L.; ROBINSON, R.; SHI, Z.; MANN, G. Efficacy of progesterone supplementation during early pregnancy in cows: a meta-analysis. Theriogenology, v.85, p.1390-1398, 2016. DOI: 10.1016/j.theriogenology.2015.12.027.

Received on December 11, 2016 and accepted on May 8, 2017

Pesq. agropec. bras., Brasília, v.53, n.1, p.105-112, Jan. 2018

DOI: 10.1590/S0100-204X2018000100012 